\title{
MANFAAT HIPNOTERAPI SPIRITUAL DALAM MENURUNKAN TINGKAT KECEMASAN MAHASISWA MENGHADAPI UJI KOMPETENSI BIDAN INDONESIA (UKBI)
}

\author{
Siti Khuzaiyah $^{1}$, Nur Chabibah ${ }^{2}$, Milatun Khanifah ${ }^{3}$ \\ Prodi DIII Kebidanan STIKES Muhammadiyah Pekajangan Pekalongan \\ Email: khuzaiyahpenulis@gmail.com
}

\begin{abstract}
ABSTRAK
Uji Kompetensi Bidan Indonesia (UKBI) adalah ujian kompetensi lulusan diploma III kebidanan untuk mendapatkan surat tanda registrasi bidan (STR). UKBI dilaksanakan dalam rangka mendapatkan kompetensi lulusan bidan yang sama di seluruh Indonesia. Persiapan dalam menghadapi ujian ini sering kali membuat stress dan cemas. Hasil studi pendahuluan terhadap 10 lulusan bidan menunjukkan bahwa 8 (80\%) Mengalami kecemasan menjelang UKBI.Salah satu teknik menurunkan kecemasan adalah dengan hipnoterapi spiritual. Hipnoterapi spiritual mampu menurunkan kecemasan karena membawa klien pada kondisi rileks, membawa otak pada gelombang alfa dan tetha, mengganti emosi kecemasan dengan emosi positif ke dalam bawah sadar meliputi ketenangan, kepasrahan, keikhlasan, penerimaan dan keyakinan.Tujuan penelitian ini adalah untuk menganalisis pengaruh hipnoterapi spiritual terhadap kecemasan bidan fresh graduate menjelang Uji Kompetensi Bidan Indonesia.Jenis penelitian yang dilakukan adalah kuantitatif quasi experimental dengan pendekatan one group sample with pretest-postets design.Sampel dalam penelitian ini adalah seluruh lulusan bidan 2017 (fresh graduate) prodi DIII Kebidanan STIKES Muhammadiyah Pekajangan Pekalongan sejumlah 57 orang. Data kecemasan diukur dengan instrument DT-MAS (The Taylor Minensota Anxiety Scale). Analisis data menggunakan paired t-test. Hasil penelitian menunjukkan bahwa hipnoterapi spiritual mampu menurunkan tingkat kecemasan mahasiswa bidan fresh graduate menjelang UKBI dengan $p$-value $=0,011$ dan $C I=0,432$ 3,217 .
\end{abstract}

Kata Kunci: hipnoterapi spiritual, kecemasan, uji kompetensi, bidan, UKBI

\section{EFFECTIVENESS OF SPIRITUAL HYPNOTHERAPY ON ANXIETY OF FRESH GRADUATE MIDWIFE TOWARD INDONESIAN MIDWIFE COMPETENCY TEST} (UKBI)

\begin{abstract}
The Indonesian Midwife Competency Test (UKBI) is a competency test for diploma III midwifery graduates to obtain the registration letter of the midwife (STR). UKBI is implemented in order to obtain the competence of the same midwife graduates throughout Indonesia. Preparing for these exams often creates a high level of stress and anxiety. A preliminary study of 10 midwife graduates showed that $8(80 \%)$ experienced anxiety ahead of UKBI. The purpose of this study is to. The purpose of this study was to analyze the influence of spiritual hypnotherapy on the anxiety of fresh graduate midwife before the Competency Test of Indonesian Midwife. The research type is quantitative quasi experimental with one group pretest-postets design approach. The samples in this research were all graduates of midwife 2017 (fresh graduate) of Diploma Midwifery at STIKES Muhammadiyah Pekajangan Pekalongan, the numbers were 57 people. Anxiety data was measured by DT-MAS instrument (The Taylor Minensota Anxiety Scale). Data analysis technique to be used is paired $\neg$ t-test. The results shows that spiritual hypnotherapy can decrease the anxiety level of fresh graduate midwife students toward of Indonesian Midwife Competency Test with p-value $=0.011$ and CI =0,432-3,217.
\end{abstract}

Keywords: spiritual hypnotherapy; anxiety; competency test; Indonesia midwife.

Jurnal SMART Kebidanan Sekolah Tinggi Ilmu Kesehatan (STIKes) Karya Husada Semarang www.stikesyahoedsmg.ac.id/ojs/index.php/sjkb 


\section{Pendahuluan}

Uji Kompetensi Bidan Indonesia (UKBI) adalah ujian kompetensi lulusan diploma III kebidanan untuk mendapatkan surat tanda registrasi bidan (STR). UKBI dilaksanakan dalam rangka mendapatkan kompetensi lulusan bidan yang sama di seluruh Indonesia. Persiapan dalam menghadapi ujian ini sering kali membuat stress dan cemas. Hasil studi pendahuluan terhadap 10 lulusan bidan menunjukkan bahwa 8 (80\%) Mengalami kecemasan menjelang UKBI. Menurut Davidoff (1991) kecemasan menyebabkan mahasiswa seolah-olah tidak dapat mengingat pelajaran apapun yang telah dipelajari sebelumnya, kecemasan dapat mempengaruhi pemberian kode, penyimpanan, atau mengingat kembali, hal ini tentunya sangat tidak menguntungkan bagi bidan menjelang ujian kompetensi karena akan berdampak pada kesiapan bidan menghadapi ujian kompetensi yang akan mempengaruhi hasil ujian.

Salah satu upaya untuk menurunkan kecemasan adalah dengan hipnoterapi.Hipnosis adalah sebuah kondisi rileks, fokus, atau konsentrasi.Kondisi hipnosis terjadi saat manusia berfokus pada kondisi internal, yang dicapai pada pola gelombang otak alpha atau lebih rendah.Pada dasarnya peran penghipnosis hanyalah sebagai pembimbing untuk menuju kondisi hipnosis yang lebih dalam, yaitu gelombang otak yang lebih dalam.Dalam penganganan kasus sederhana, seperti membangkitkan motivasi, manusia dapat melakukan hipnosis pada diri sendiri.Namun, untuk penanganan kasus yang lebih kompleks dibutuhkan seorang pembimbing untuk memasuki tahap relaksasi yang lebih dalam dan membantu pemberian sugesti-sugesti (Wong, 2009).Spiritual hypnotherapy adalah hipnoterapi dengan memasukkan unsur kemahakuasaan Tuhan di dalamnya.

Irianto, dkk (2014) menyebutkan ada pengaruh hipnoterapi terhadap penurunan tingkat kecemasan pasien saat menjalani kemoterapi dengan $p$ value 0,000. Hipnoterapi juga efektif menurunkan derajat kecemasan dan gatal pada pasien dengan liken simpleks kronik dengan $p$ value 0,031 (Novrizal, 2010).

\section{Tinjauan Teoritis}

Uji Kompetensi Bidan Indonesia adalah suatu uji untuk menilai kompetensi lulusan bidan di Indonesia. Ujian Kompetensi memang wajib dilakukan karena sudah ada undang-undang yang mengaturnya yaitu didasarkan pada UU No 20 Th 2003, Pasal 61 ayat 3 yang menyebutkan bahwa sertifikat kompetensi diberikan oleh penyelenggara pendidikan dan lembaga pelatihan kepada peserta didik dan warga masyarakat sebagai pengakuan terhadap Jurnal SMART Kebidanan Sekolah Tinggi Ilmu Kesehatan (STIKes) Karya Husada Semarang www.stikesyahoedsmg.ac.id/ojs/index.php/sjkb 
kompetensi untuk melakukan pekerjaan tertentu setelah lulus uji kompetensi yg diselenggarakan oleh satuan pendidikan yang terakreditasi atau lembaga sertifikas, peraturan lain yaitu PP no 19 Th 2005, pasal 89 ayat 5 menyebutkan bahwa sertifikat kompetensi diterbitkan oleh satuan pendidikan yang terakreditasi atau lembaga sertifikasi mandiri yang dibentuk oleh organisasi profesi yang diakui Pemerintah sebagai tanda bahwa peserta didik yang bersangkutan telah lulus uji kompetensi. Tuntunan adanya uji kompetensi diperkuat dengan adanya Permen no 70 tahun 2008 tanggal 26 nopember 2008 tentang Uji Kompetensi Bagi Peserta Didik Kursus dan Warga Masyarakat. Sasaran uji kompetensi bidan Indonesia adalah lulusan bidan (fresh graduate) sebelum mereka terjun langsung menjalani profesi mereka. Metode uji kompetensi bidan di Indonesia adalah dengan paper best test (PBT).

\section{Kecemasan Menjelang Uji Kompetensi Bidan Indonesia}

Kecemasan adalah hasil dari proses psikologis dan fisiologis dalam tubuh manusia yang dirasakan sebagai reaksi terhadap bahaya yang mungkin menimbulkan bencana, terutama jika ada tekanan perasaan atau tekanan jiwa yang amat sangat dan orang yang bersangkutan kehilangan kendali dalam situasi yang dialami (Ramaiah, 2003). Kecemasan harus dibedakan dengan rasa takut dimana obyek kecemasan biasanya tidak jelas, dan intensitas kecemasan sering kali jauh lebih besar daripada obyeknya, sedangkan obyek dari ketakutan biasanya mudah dispesifikasikan dan intensitas rasa takut sesuai dengan besar kecilnya ancaman (Linda L Davidoff, 1991).Kecemasan disebabkan oleh berbagai hal yaitu lingkungan, emosi yang ditekan, sebab-sebab fisik dan keturunan (Ramaiah, 2003). Ketika seseorang mengalami kecemasan, akan muncul respon baik fisik, perilaku, kognitif dan afektif. Respon fisik seperti adanya perubahan di sistem kardiovaskuler, sistem pernafasan, sistem neurovaskuler, sistem gastrointestinal dan sistem urinaria.Respon lain dari kecemasan adalah gelisah, ketegangan fisik, gugup, bicara cepat, kurang koordinasi, konsentrasi buruk, pelupa, salah dalam memberikan penilaian, hambatan berfikir, produktivitas menurun, bingung, mudah terganggu, tidak sabar tegang, gugup dan ketakutan.Kecemasan dapat diukur dengan menggunakan The Taylor Minensota Anxiety Scale (TMAS).

Dampak dari kecemasan adalah menurunnya motivasi dan meningkatkan ketegangan.Kecemasan dapat muncul apabila ada suatu pencetus.Semakin dekatnya waktu menjelang uji kompetensi bidan dapat memicu terjadinya kecemasan bagi bidan.Kecemasan 
ini harus dikelola dengan baik agar tidak berdampak pada menurunnya motivasi belajar dan menurunnya hasil uji kompetensi bidan.

\section{Pengaruh Hipnoterapi Spiritual terhadap Kecemasan}

Kecemasan menimbulkan respon negatif, baik berupa fisik, perilaku, kognitif maupun afektif sehinggadiperlukan pengelolaan secara baik.Salah satu jenis manajemen emosi adalah dengan spiritual hypnotherapy(hipnoterapi spiritual).Hipnosis adalah suatu metode komunikasi yang efektif untuk memasukkan informasi atau ide baru ke dalam pikiran bawah sadar seseorang termasuk diri sendiri.Hipnosis mempunyai kelebihan dalam efektivitas berkomunikasi karena mampu membypass critical factor sehingga informasi atau sugesti lebih mudah masuk ke dalam pikiran bawah sadar (Adiyanto, 2010).Hipnosis telah terbukti secara medis bisa mengatasi berbagai macam gangguan psikologis maupun fisik (Majid, 2013, dan Wong, 2009).

Hipnosis adalah sebuah kondisi rileks, fokus, atau konsentrasi.Kondisi hipnosis terjadi saat manusia berfokus pada kondisi internal, yang dicapai pada pola gelombang otak alpha atau lebih rendah.Pada dasarnya peran penghipnosis hanyalah sebagai pembimbing untuk menuju kondisi hipnosis yang lebih dalam, yaitu gelombang otak yang lebih dalam.Dalam penganganan kasus sederhana, seperti membangkitkan motivasi, manusia dapat melakukan hipnosis pada diri sendiri.Namun, untuk penanganan kasus yang lebih kompleks dibutuhkan seorang pembimbing untuk memasuki tahap relaksasi yang lebih dalam dan membantu pemberian sugesti-sugesti (Wong, 2009).

Spiritual adalah sesuatu yang berhubungan dengan atau bersifat kejiwaan (rohani, batin). Spiritualitas adalah sumber motivasi dan emosi pencarian individu yang berkenaan dengan hubungan seseorang dengan Tuhan (KBBI, 2016).

Spiritual hypnotherapy adalah hipnoterapi dengan memasukkan unsur kemahakuasaan Tuhan di dalamnya. Penelitian Irianto, dkk (2014) menyebutkan bahwa ada pengaruh hipnoterapi terhadap penurunan tingkat kecemasan pasien saat menjalani kemoterapi dengan $p$ value 0,000 . Hipnoterapi juga efektif menurunkan derajat kecemasan dan gatal pada pasien dengan liken simpleks kronik dengan $p$ value 0,031 (Novrizal 2010). Selain menurunkan kecemasan, hipnoterapi dalam konsep pembelajaran juga dapat meningkatkan motivasi belajar.Penelitian Hasbulloh dan Rahmawati (2015) menyebutkan 
bahwa terdapat pengaruh metode hypnoteaching terhadap motivasi belajar bahasa inggris mahasiswa program studi Pendidikan Matematika UNINDRA PGRI.

\section{Metode Penelitian}

Desain penelitian ini adalah quasi experiment with one group pre-post test design.Populasi seluruh mahasiswa bidan fresh graduate STIKES Muhammadiyah Pekajangan 2017. Total sampel dalam penelitian ini adalah 57 orang. Kesemasan diukur dengan menggunakan instrumen D.T - MAS (The Taylor Minensota Anxiety Scale).Kecemasan diukur 2x, yaitu sebelum dan setelah dilakukan hipnoterapi. Hipnoterapi menggunakan pendekatan hipnoterapi spiritual, menggabungkan unsur agama dan kepasrahan kepada sang Kuasa Alloh SWT. Data yang diperoleh diolah menggunakan analisis univariat dan bivariate yaitu dengan paired t-test.

\section{Hasil Penelitian}

Perbedaan Kecemasan Sebelum dan Sesudah Hipnoterapi Spiritual Hipnoterapi

Tabel 1. Perbedaan Kecemasan sebelum dan sesudah Hipnoterapi Spiritual

\begin{tabular}{|c|c|c|c|c|c|c|c|c|c|}
\hline No & Kecemasan & Mean \pm SD & Min & Max & Kat & ri n $(\%)$ & $\mathrm{N}$ & $C I$ & $p$-value \\
\hline 1 & $\begin{array}{l}\text { Sebelum } \\
\text { Hipnoterapi }\end{array}$ & $\begin{array}{l}24.75 \pm \\
5.36\end{array}$ & 15 & 38 & $\begin{array}{l}\text { Cemas } \\
\text { Tidak }\end{array}$ & & 57 & & \\
\hline 2 & Setelah Hipnoterapi & $\begin{array}{l}22.93 \pm \\
6.15\end{array}$ & 8 & 37 & $\begin{array}{l}\text { Cemas } \\
\text { Tidak } \\
\text { Cemas }\end{array}$ & $\begin{array}{l}35(61.40) \\
22(38.60)\end{array}$ & 57 & $\begin{array}{c}0.432- \\
3.217\end{array}$ & $0,011^{*}$ \\
\hline
\end{tabular}

*Paired t-test

Tabel 1 menunjukkan bahwa rata-rata skor kecemasan responden sebelum dilakukan hipnoterapi spiritual adalah 24,75 \pm 5.36 dengan skor minimal 15 dan skor maksimal 38 . Berdasarkan analisis kategori menunjukkan bahwa jumlah responden yang cemas mencapai $75,44 \%$ yang berarti bahwa sebagian besar responden mengalami kecemasan menjelang UKBI. Skor kecemasan responden setelah dilakukan hipnoterapi spiritual mengalami penurunan dengan rata-rata skor kecemasan $22.93 \pm 6.15$, skor minimal 8 dan skor maksimal 37. Data ini menunjukkan bahwa terjadi penurunan rerata skor dan penurunan skor secara umum dilihat dari nilai minimum dan maksimum. Analisis lebih lanjut secara bivariat Jurnal SMART Kebidanan Sekolah Tinggi Ilmu Kesehatan (STIKes) Karya Husada Semarang www.stikesyahoedsmg.ac.id/ojs/index.php/sjkb 
menggunakan paired t-test menunjukkan perbedaan yang signifikan antara skor kecemasan sebelum dan sesudah dilakukan hipnoterapi spiritual dengan $p$ value sebesar 0,011 dan $C I$ $0,432-3,217$.

\section{Pembahasan}

Kecemasan adalah hasil dari proses psikologis dan fisiologis dalam tubuh manusia yang dirasakan sebagai reaksi terhadap bahaya yang mungkin menimbulkan bencana, terutama jika ada tekanan perasaan atau tekanan jiwa yang amat sangat dan orang yang bersangkutan kehilangan kendali dalam situasi yang dialami. Kecemasan disebabkan oleh berbagai hal yaitu lingkungan, emosi yang ditekan, sebab-sebab fisik dan keturunan (Ramaiah, 2003). Ketika seseorang mengalami kecemasan, akan muncul respon baik fisik, perilaku, kognitif dan afektif. Respon fisik seperti adanya perubahan di sistem kardiovaskuler, sistem pernafasan, sistem neurovaskuler, sistem gastrointerstinal dan sistem urinaria. Respon lain dari kecemasan adalah gelisah, ketegangan fisik, gugup, bicara cepat, kurang koordinasi, konsentrasi buruk, pelupa, salah dalam memberikan penilaian, hambatan berfikir, produktivitas menurun, bingung, mudah terganggu, tidak sabar tegang, gugup dan ketakutan.Kecemasan dapat diukur dengan menggunakan The Taylor Minensota Anxiety Scale (TMAS). Dampak dari kecemasan adalah menurunnya motivasi dan meningkatkan ketegangan. Kecemasan dapat muncul apabila ada suatu pencetus. Semakin dekatnya waktu menjelang uji kompetensi bidan dapat menjadi pencetus yang memicu terjadinya kecemasan bagi mahasiswa bidan fresh graduate.Kecemasan ini harus dikelola dengan baik agar tidak berdampak pada menurunnya motivasi belajar dan menurunnya hasil uji kompetensi bidan.

Salah satu cara menglola kecemasan dan meningkatkan hasil uji kompetensi adalah dengan melakukan manajemen emosi yang salah satunya dengan spiritual hypnotherapy. Hipnoterapi adalah suatu metode komunikasi terapi yang efektif untuk memasukkan informasi atau ide baru ke dalam pikiran bawah sadar seseorang termasuk diri sendiri.Hipnoterapi mempunyai kelebihan dalam membypass critical factor sehingga informasi atau sugesti lebih mudah masuk ke dalam pikiran bawah sadar (Adiyanto, 2010).Hipnoterapi telah terbukti secara medis bisa mengatasi berbagai macam gangguan psikologis maupun fisik (Majid, 2013, dan Wong, 2009).

Hipnoterapi merupakan bagian dari hipnosis yang berfokus pada penyembuhan.Hipnosis adalah sebuah kondisi rileks, fokus, atau konsentrasi.Kondisi hipnosis 
terjadi saat manusia berfokus pada kondisi internal, yang dicapai pada pola gelombang otak alpha atau lebih rendah.Pada dasarnya peran penghipnosis hanyalah sebagai pembimbing untuk menuju kondisi hipnosis yang lebih dalam, yaitu gelombang otak yang lebih dalam.Dalam penganganan kasus sederhana, seperti membangkitkan motivasi, manusia dapat melakukan hipnosis pada diri sendiri. Namun, untuk penanganan kasus yang lebih kompleks dibutuhkan seorang pembimbing untuk memasuki tahap relaksasi yang lebih dalam dan membantu dalam pemberian sugesti-sugesti (Wong, 2009). Spiritual hypnotherapy adalah hipnoterapi dengan memasukkan unsur kemahakuasaan Tuhan di dalamnya.

Pada penelitian ini terapis hipnoterapi membawa pasien pada kondisi bawah sadar, membimbing responden untuk membuang emosi negatif, mengganti dengan emosi positif, membangun kesadaran diri, serta memasang anchor semangat dan sukses pada responden.Anchor adalah sugesti berupa simbol-simbol yang akan menghasilkan reaksi pemikiran, emosional, atau perilaku tertentu. Anchor ini memiiliki manfaat dalam terapi. Penelitian Budiman (2016) menyebutkan bahwa Ada Pengaruh Hipnoterapi spiritual dengan Teknik Anchor terhadap Perubahan Perilaku Merokok Remaja. Hal ini dibuktikan hasil uji yaitu Uji statistik dengan $t$ berpasangan diperoleh nilai ( $p$ value) sebesar 0,00 lebih kecil dari alpa 0,05 yang berarti bahwa ada pengaruh Program hipnoterapi dengan metode anchor terhadap perilaku merokok remaja. Hipnoterapi juga dapat digunakan sebagai metode terapi pada kasus post traumatic stress disorder (PTSD) dengan pendekatan cognitive-behavioural termasuk ddi dalamnya dengan terapi pikiran (Lynn, et.all, 2012).

Pada kondisi bawah sadar ini terapis juga membimbing para responden untuk menentukan target yang akan dicapai dalam setahun ke depan, terutama target untuk lulus uji kompetensi. Responden juga diminta untuk membayangkan saat responden sudah mencapai sukses. Dalam kajian hipnoterapi, aktivitas membimbing klien untuk membayangkan yang indah (termasuk membayangkan kesuksesan) disebut sebagai guided imagery. Guided imagery adalah intervensi yang fleksibel dan telah diteliti puluhan tahun pada bidang konseling dan yang berkaitan dengan konseling (Utay, et.all 2006). Guided imagery (imajinasi terpimpin) merupakan tehnik relaksasi yang memberikan kontrol pada pasien sehingga memberikan kenyamanan fisik dan mental (Petter \& Perry, 2006).

Apostolo, etc (2003) menyebutkan bahwa pengukuran berulang pada uji efektivitas guided imagery terhadap kenyamanan, depresi, kecemasan dan stress pasien psikiatri dengan gangguan depresi menunjukkan bahwa guided imagery secara signifikan mampu 
meningkatkan kenyamanan pasien dan menurunkan tingkat depresi, kecemasan dan stress.

Aspek hipnoterapi spiritual dengan memasukkan unsur ketuhanan di dalamnya dengan menuntun responden untuk mengingat Tuhan, berusaha maksimal, pasrah, ikhlas dan yakin bahwa dengan kekuasaan Tuhan maka segala hal dapat terjadi.Responden dituntun untuk semakin mendekat kepada Allah SWT.

Studi secara random dan progressif dengan pemantauan selama 2 tahun terhadap anakanak depresi yang mendapat seragangan bom bali menunjukkan bahwa metode hipnosis spiritual sangat efektif, ekonomis dan mudah diimplementasikan dan terbukti bermanfaat untuk terapi PTSD dengan peningkatan rata-rata kesembuhan klien mencapai 77,1\%, dimana ini lebih tinggi dibanding hanya $24 \%$ pada kelompok kontrol yang tidak mendapat terapi (Lesmana, et.all, 2011).

Penelitian Irianto, dkk (2014) menyebutkan bahwa ada pengaruh hipnoterapi terhadap penurunan tingkat kecemasan pasien saat menjalani kemoterapi dengan $p$ value0,000. Hipnoterapi juga efektif menurunkan derajat kecemasan dan gatal pada pasien dengan liken simpleks kronik dengan $p$ value 0,031 (Novrizal 2010).

\section{Kesimpulan}

Hasil penelitian menunjukkan bahwa hipnoterapi spiritual dapat menurunkan secara signifikan tingkat kecemasan mahasiswa bidan fresh graduate menjelang UKBI.

\section{Saran}

Bagi institusi kebidanan dapat mempertimbangkan penggunaan metode hinoterapi spiritual sebagai salah satu cara menurunkan tingkat kecemasan para mahasiswa ketika menjelang ujian, khususnya menjelang uji kompetensi 


\section{Daftar Pustaka}

Adiyanto, Lelik, 2009, Smartbirthing: Panduan Praktis Hipnosis Bagi Kehamilan dan Persalinan, UNDIP Pers

Apostolo JLA \& Kolcaba K, 2009, The Effects of Guided Imagery on Comfort, Depression, Anxiety, and Stress of Psychiatric Inpatients with Depressive Disorders. Archives of Psychiatric Nursing. Volume 23, Issue 6, December 2009, Pages 403-411 https://doi.org/10.1016/j.apnu.2008.12.003

Budiman, 2016, Efektivitas Hypnoterapi Teknik Anchor Terhadap Perubahan Perilaku Merokok Remaja.PSIKIS_Jurnal Psikologi Islam Vol.2 No.2 (2016) 135-148 Hasbulloh \& Rahma, 2015, Pengaruh Penerapan Hipnoteaching terhadap Motivasi Belajar Mahasiswa Universitas Indraprasta PGRI, Jurnal Formatif 5(1):83-90, 2015 Irianto, dkk, 2014, Pengaruh Hipnoterapi terhadap Penurunan Tingkat Kecemasan pada Pasien yang Menghadapi Kemoterapi

Kemdikbud. 2016. KBBI Daring. https://kbbi.kemdikbud.go.id/entri/spiritualitas

Lesmana, CBJ, Suryani LK, GD Jensen, Tilopoulos N, 2011, A Spiritual-Hypnosis Assisted Treatment of Children with PTSD after the 2002 Bali Terrorist Attack. American Journal of Clinical Hypnosis, Volume 52, 2009 - Issue 1. ages 23-34 | Published online: 21 Sep 2011 https://doi.org/10.1080/00029157.2009.10401689

Lynn S, Malakataris A, Condon L, Maxwell R \& Cleere C, 2012 , Post-traumatic Stress Disorder: Cognitive Hypnotherapy, Mindfulness, and Acceptance-Based Treatment Approaches, American Journal of Clinical Hypnosis. Volume 54, 2012 - Issue 4: Pages 311-330 | Published online: 26 Mar 2012.

https://doi.org/10.1080/00029157.2011.645913

Novrizal, R. \& Pengantar, K., 2010.Keefektifan Hipnoterapi Terhadap Penurunan Derajat Kecemasan dan Gatal Pasien Liken Simpleks Kronik Di Poliklinik Penyakit Kulit Dan Kelamin RSDM Surakarta PROGRAM PENDIDIKAN DOKTER SPESIALIS I PSIKIATRI.

Utay, Joe; Miller, Megan. 2006. Guided Imagery as an Effective Therapeutic Technique: A Brief Review of its History and Efficacy Research. Journal of Instructional Psychology . Mar2006, Vol. 33 Issue 1, p40-43. 4p.

Wong. W, and Hakim A, Dahsyatnya Hipnosis, Visimedia, Jakarta, 2009, 87-91. 